\title{
Release of tri-butyl phosphate from sediments to waters : how to assess a potential impact on biota at environmental concentrations ?
}

\author{
RENAUD FLEUROT ${ }^{1}$, ESMERALDA NARAIN ${ }^{1}$, ANNE \\ DUITTOZ $^{1}$ AND CECILE GROSBOIS ${ }^{2}$ \\ ${ }^{1}$ University of Tours - INRAe \\ ${ }^{2}$ University of Tours \\ Presenting Author: cecile.grosbois@univ-tours.fr
}

In fluvial systems, organic and metallic contaminants, mainly hydrophobic, are often trapped in bank and bed sediments. Therefore, one major threat for the environment, i.e. water resources quality and biota, is when this cocktail of contaminants is released from sediments into interstitial and surface waters. A main question is about the potential impact of this cocktail at environmental concentrations, so much lower than the determined potential effect concentrations.

In this study, batch experiments were carried out on contaminant-enriched bed sediments (see Grosbois et al, session 11). Even though these studied sediments were not highly concentrated in tri-butyl phosphate (TBP; $\mathrm{C}_{12} \mathrm{H}_{27} \mathrm{O}_{4} \mathrm{P}$; about 250 ng/g dry wt), the leachates contained this compound with a TBP maximum concentration about $2 \mathrm{nmol} / \mathrm{L}$.

TBP belongs to the organophosphorus flame retardants (OPFRs), massively used since the 1970s as alternative to the brominated flame retardants (BFRs) that are currently banned. TBP is ubiquitous and persistent in the environment (Gao-Ling et al, 2015; Pantelaki and Voutsa, 2019) and suspected to induce neurotoxic effects (van der Veen and de Boer, 2012) with an averaged cellular toxicity around $10 \mathrm{mmol} / \mathrm{L}$ (ToxCast data). The real potential risk for biota was evaluated here with this leachate environmental concentration and in vitro cellular tests focusing on neural development.

We chose the neurosphere assay (Reynolds and Weiss, 1992) which recapitulates the main developmental phases: neural stem cell proliferation, progenitor migration, neuronal or glial differentiation. We tested two TBP concentrations (2nM and 10 times, $20 \mathrm{nM}$ ), a negative control (vehicle) and a positive control containing $10 \mathrm{mM}$ lithium chloride which increases neural stem cells proliferation and favors neuronal differentiation. In the presence of TBP 2 and $20 \mathrm{nM}$, we observed a significant decrease in neural stem cell proliferation by $50 \%$ but no difference in the cellular differentiation was detected.

TBP is effective at decreasing neural stem cell proliferation in a murine neurosphere assay at a concentration 500 times less that the average concentration inducing cellular toxicity. TBP release from sediments could therefore represent a potential negative impact on the development of aquatic larvae and embryo fauna forms, even at very low concentrations. 